\title{
The Influences of Lime Powder (Citrus aurantifolia, S.) on Hibiscus Leaf Tea Quality (Hibiscus rosasinensis, L.)
}

\author{
Sahadi Didi Ismanto ${ }^{\#}$, Tuty Anggraini ${ }^{\#}$ and Melda Fitri J.Nst. ${ }^{\#}$ \\ \# Faculty of Agricultural Technology, Andalas University, Padang, Indonesia \\ E-mail: sahadididiismanto@gmail.com
}

\begin{abstract}
This first aim of the study is to look the influence of different lime powder concentration level addition to hibiscus leaf dip drink's quality. Then, the Second influence of different lime powder for tea hibiscus leaf which accepted as best sensory analysis. The study was conducted from August to September 2014 in the Agricultural Technology Laboratory and Tablet preparation laboratory Pharmacy, University of Andalas, Padang Indonesia. This study is used complete randomized design (CRD) consisting of 4 treatments and 3 replications. The data were analyzed by using ANOVA statistically and Duncan's New Multiple Range (DNMRT) at 5\% significance level. The Treatment in this study is the addition of lime powder by $55 \%, 65 \%, 75 \%$, and $85 \%$. Observations of hibiscus leaf powder and lime powder such us water content, ash content, vitamin $\mathrm{C}$ and antioxidants, while product tea hibiscus leaf such water content, ash content, vitamin $\mathrm{C}$, antioxidants, poly phenols, sensory analysis, and total plate count of it. The result of the study is showed that the addition of lime powder influence on water content, ash content, vitamin C, and antioxidants. Based sensory analysis and chemical analysis, the best beverage products hibiscus leaves are dipped in treatment $\mathrm{A}$ (addition of lime powder $55 \%$ ) with a $45 \%$ level of liking the taste, flavor and color of $75 \%$ and $55 \%$, vitamin $\mathrm{C} 0.15 \%, 1.58 \%$ total poly phenols, antioxidant activity of $35.51 \%$, total plate count was $2.83 \times 103 \mathrm{cfu} / \mathrm{ml}, 7.76 \%$ water content and ash content of $9.87 \%$.
\end{abstract}

Keywords - Antioxidant; Lime powder; Tea hibiscus leaf; tea quality

\section{INTRODUCTION}

Medicinal plants have long been known and used in an effort to address the problem health. Herbal drinks market has developing the flavor and aroma are favored society. Drink herbal tea in the form of ready food is one of the diversified products business herbs that have been developed at this time. In Indonesia, herbal drinks increasingly in demand in line with the level of public awareness of the importance of health and the high demand traditional medicines. This is reinforced by the numbers higher recovery from drug use herbs [1]. Herbal teas can be made from herbs, one potential as a medicinal plant in Indonesia has been used for generations in the tradition people are hibiscus (Hibiscus rosasinensis, L.). This beautiful flowering plants planted to decorate the home page and in Empirical is used as a skin softener, laxative sputum, mouth sores and fever [2]. The hibiscus is a shrub originated from East Asia and widely planted as ornamental plants in the tropics and subtropics. The flowers large, red and odorless. Flowers from various cultivars and hybrids may be of interest single (leaf crown layer) or double flowers (leaf plated crown) white to yellow, orange to dark red or pink [3].
Hibiscus leaves contain compounds chemicals, flavonoids, polyphenols and saponins. flavonoids and polyphenols act as antioxidants, saponins a surface active compounds which have antimicrobial effect on the body [4]. With the chemical content is and has efficacy as drugs - drugs, expected hibiscus leaves can be so it can be used as a tea with easy to use for the treatment, and also intended to increase diversity product, use value and economic value as well extend the shelf life. Hibiscus leaves used in the manufacture of this tea is a leaf hibiscus with white flowers as has been frequently used as a community for a long time herbal medicine.

Diversification in the manufacture of tea leaf hibiscus required to produce flavor preferred. The addition of other ingredients such as citrus lime that has health benefits because contain citric acid as much as 7 to $7.6 \%$, and oranges vitamin $\mathrm{C}$ as much as $27 \mathrm{mg} / 100 \mathrm{~g}$ orange, can play a role as an antioxidant [5]. Lime can used as a traditional medicine that is efficacious to reduce fever, cough, urinary tract infections, dandruff, increase stamina, reduce acne as well as anti-inflammatory and antimicrobial [6].

Based on research Ahza et al [7] in the manufacture of a mixture of extracts Microencapsulation peel and lemon (Citrus aurantifolia, S) and application on the material obtained tea the addition of lemon juice powder made from 
filler mixture of gum arabic: dextrin (1: 1) with concentration of $25 \%$, the best sensory quality (especially flavor and color), vitamin $\mathrm{C}$ is high enough (11833 $\mathrm{mg} / 100 \mathrm{~g}$ ), the proportion of powdered orange juice lime $75 \%$ of the weight of tea in tea-making application, quality steeping lemon tea produced is very panelists preferred. Purpose of this study was to determine the effect of adding an orange powder concentration level the effect of adding an orange powder concentration level lime disproportionately on the quality of tea leaf flower shoes and to determine the effect of powdered lime against the best formulation produced with the level of acceptance of the panelists.

\section{MATERIALS AND METHODS}

\section{A. Place and Time}

This research has been conducted in Process Engineering and Technology Laboratory, Chemistry Biochemistry Agricultural Products and Nutrition Programs Agricultural Technology, and Laboratorium preparations Tablet Faculty of Pharmacy at the University of Andalas In AugustSeptember, 2014.

\section{B. Materials and Equipment}

The main raw materials used in This study is a leaf hibiscus obtained from one of the people in the yard Koto Tingga. Lemon that came from highway market Padang. Packaged is used tea bags dye (tea bag) as primary packaging and packaging metal foil as a secondary packaging. Chemicals used are: DPPH (400 m), 90\% methanol, distilled water, Follin-Ciocalteu reagent $(50 \%)$, $\mathrm{Na} 2 \mathrm{CO} 3(5 \%)$, PCA, agar, starch $1 \%$, and iodine $0,01 \mathrm{~N}$. Tools needed in research knife, oven, scissors, paper filter, spoon stirrer, trays sterile, tissue, electric stove, and a dry blender. Tool used in the analysis is the measuring cup, porcelain plate, aluminum plate, a petri dish, pumpkin measuring $10 \mathrm{ml}$ test tube, vortex, aluminum foil, erlenmeyer, analytical balance, pipette, strainer, furnaces, heating destruction, spectrophotometer, oven, and desiccator.

\section{Study Design}

This study was designed to use Complete Randomized Design (CRD) with 4 treatments and 3 replications. This type of treatment consists of: $\mathrm{A}=$ Addition Powder Lime $55 \% ; \mathrm{B}=$ Addition Powder Lime 65\% ; $\mathrm{C}=$ Addition Powder Lime $75 \%$ and D = Addition Powder Lime $85 \%$.

\section{Implementation Research}

Preparation of powdered leaves of hibiscus [8]. Stages of manufacture of powdered leaves Flower Shoes as follows: (1) Picking fresh hibiscus leaf color Dark green, then washed and drained. (2) Inactivation of the enzyme leaves the flower shoes steam. (3) Drying oven with a temperature of $70^{\circ} \mathrm{C}$ until the water content of $4 \%-6 \%$. (4) Shrinking the size of a blender until resembles a powder.

\section{E. Preparation of Powder Lime [16]}

Manufacture of extracts of lemon juice done by: (1) Citrus fruit juice sorted, washed; (2) Split into two, squeezed or pressed and filtered with filter cloth; (3) Take lemon citrus fruit extracts; (4) Having obtained lemon extract, add malto dextrin concentration of $20 \%$ of the orange extract lime; (5)
Stirred (homogenized) for 15 minutes or until dissolved and (6) Drained by using a spray dryer a temperature of $160^{\circ} \mathrm{C}$ for 1 hour.

\section{F. Process Hibiscus Tea Leaves with the addition of powder Lime}

Stages of manufacture of tea leaf hibiscus with the addition of powdered lime as follows: (1) The powder was added powdered leaves of Hibiscus lime with a number of hibiscus leaves 2 grams according to treatment: $\mathrm{A}=1.1 \mathrm{~g}, \mathrm{~B}$ $=1.3 \mathrm{~g}, \mathrm{C}=1.5 \mathrm{~g}$, and $\mathrm{D}=1.7 \mathrm{~g}$, per sachet tea bag and (2) The formulation has been mixed packaged in teabag further coated with metal foil packaging.

TABLE I

FORMULATION TEA

\begin{tabular}{|l|c|c|c|c|}
\hline \multirow{2}{*}{ Material } & \multicolumn{4}{|c|}{ Treatment } \\
\cline { 2 - 5 } & A & B & C & D \\
\hline Flower leaf powder shoes $(\mathrm{g})$ & 2 & 2 & 2 & 2 \\
\hline Powdered lime $(\mathrm{g})$ & 1,1 & 1,3 & 1,5 & 1,7 \\
\hline
\end{tabular}

\section{RESULTS AND DISCUSSION}

\section{A. Analysis of Raw Materials}

The analysis conducted on the raw materials hibiscus leaf powder is water content, content ash and antioxidant activity. Raw materials used in this study are leaf flower old shoes (starting from the fifth leaf from the top) that contains flavonoids. The treatment given tohibiscus tea leaves by adding powdered lime. At the powdered lime test vitamin $\mathrm{C}$, antioxidant activity, moisture content and levels ash. Results of the analysis of the raw material leaves visible in Table 2.

TABLE II

RESUlts of ANALysis of RAW MATERIAL POWdER LEAVES Hibiscus AND LIME POWDER.

\begin{tabular}{|l|c|c|}
\hline Parameter (\%) & $\begin{array}{c}\text { Powdered leaves } \\
\text { of hibiscus }\end{array}$ & $\begin{array}{c}\text { Lime } \\
\text { Powder }\end{array}$ \\
\hline Water Content & 4,90 & 6,41 \\
\hline Ash Content & 9,97 & 1,41 \\
\hline Vitamin C & 0,26 & 0,72 \\
\hline Antioxidant activity & 38,09 & 17,90 \\
\hline
\end{tabular}

1) Water Content: The water content of the average obtained in powder hibiscus leaves is $4.90 \%$ and the average water content powdered lime $6.41 \%$. Raw materials used is a powdered leaves of hibiscus which has undergone a drying process using the oven. The water content of the raw material powder hibiscus leaves meets the ISO standard 014453-1998 Green tea is a maximum of $8 \%$ [9]. According to Winarno [10], water content and activity Water is very influential in determining and fixing the shelf life of food, because these variables will affect the physical, physicochemical, changes chemical and enzymatic changes including. Also microbiological changes, both in food Unprocessed and processed food.

2) Ash Content: Average ash content of powdered leaf flower footwear, namely $9.97 \%$. Ash content in tea leaves hibiscus meet SNI 01- Green Tea Bags 4324-1996 is a maximum of $10 \%$. While the ash content. Average powdered 
lime is $1.54 \%$. according to Sudarmadji [11], levels ash derived from mineral elements and chemical composition that is not evaporated during the incineration process. Level high ash on a diet then mineral contained therein is also higher.

3) Vitamin $C$ : Results of analysis of vitamin $\mathrm{C}$ were performed to powder hibiscus leaves $0: 26 \mathrm{mg} / 100 \mathrm{~g}$ and lemon fruit powder obtained an average yield $0.72 \mathrm{mg} /$ $100 \mathrm{~g}$. Vitamin C is a white crystal easily soluble in water. Vitamin $\mathrm{C}$, also called as ascorbic acid is soluble vitamins in water. In the dry state of vitamin $\mathrm{C}$ sufficient stable, but in a state of soluble, vitamin $\mathrm{C}$ easily damaged by contact with the air (oxidation) especially when exposed to heat [12].

4) Antioxidant : In this study used the leaves hibiscus old (starting from the fifth leaf from shoots) having an average antioxidant that is $38.09 \%$ and powdered lime average is $17.90 \%$ at a concentration of $2500 \mathrm{ppm}$. Chemical components in hibiscus leaves that act as antioxidants are polyphenols, flavonoids and saponins. While Orange juice contains vitamin C [13]. DPPH reagent used is that is a free radical compounds. DPPH contains one or more unpaired electrons and are very reactive. Antioxidant compounds contained in sample serves to stabilize free radicals DPPH. DPPH compounds react with the compound antioxidants through retrieval of a hydrogen atom antioxidant compounds to get couples electron [14].

\section{B. Shoe flower tea leaves with addition of Lime Powder}

1) Water Content : Results of variance showed additions powdered lime significant effect on water content hibiscus tea leaves at $5 \%$ significance level. Value the average ash content in the leaves of hibiscus tea can be seen in Table 3.

TABLE III

The Water Content of TeA Leaves With Hibiscus The AdDition OF POWDERED LIME

\begin{tabular}{|l|c|}
\hline Addition of Lime Powder (\%) & Water Content (\%) \\
\hline A $(55 \%)$ & 7,76 a \\
\hline B $(65 \%)$ & 7,92 a \\
\hline C $(75 \%)$ & 7,99 a \\
\hline D $(85 \%)$ & 8,97 b \\
\hline CC $=0.13 \%$ & \\
\hline
\end{tabular}

Note: The numbers in the same column followed by small letters are not significantly different at the level of $5 \%$ by DNMRT

The average percentage of water content obtained the leaves of hibiscus tea research with the addition of lime powder ranges between $7.76 \%$ up to $8.6 \%$. The highest water content produced in D treatment (addition of powdered lime $85 \%$ ) ie $8.97 \%$ while the moisture content produced the lowest in the treatment of A (Addition of powdered lime $55 \%$ ) is $7.76 \%$. The results above show more many additional lime powder to tea hibiscus leaves the moisture content obtained more increasing. The moisture content of the raw material powder hibiscus tea leaves as many as $4.90 \%$ while the powdered lime as much as $6.41 \%$. so that the water content increases with increasing the percentage of powdered lime. Based on Green Tea SNI 014453-1998 value Water levels for green tea products a maximum of $8 \%$. This indicating that the hibiscus leaf tea products with the addition of powdered lime is not beyond the maximum limit of the water content in treatment $\mathrm{A}, \mathrm{B}$, and C of Green Tea SNI 01-4453-1998 [15]. But beyond the treatment of D. According to Buckle et al [16], the water content is very influential in the determination and the determination of future store food, as it will affect the nature physical, chemical changes, and changes Enzymatic including microbiological changes, either the food is not processed or processed food.

2) The Ash Content : Results of variance showed additions powdered lime significant effect on water content hibiscus tea leaves at $5 \%$ significance level $\alpha$. Value Average water content in the leaves of hibiscus tea can be seen in Table 4.

TABLE IV

The Water Content of Tea Leaves with Hibiscus The AdDition OF POWDERED LIME

\begin{tabular}{|l|c|}
\hline Addition of Lime Powder (\%) & Ash Content (\%) \\
\hline A (55\%) & $9,87 \mathrm{~b}$ \\
\hline B (65\%) & $9,75 \mathrm{~b}$ \\
\hline C (75\%) & $7,79 \mathrm{a}$ \\
\hline D (85\%) & $7,56 \mathrm{a}$ \\
\hline CC $=1.24 \%$ & \\
\hline
\end{tabular}

Note: The numbers in the same column followed by small letters are not significantly different at the level of $5 \%$ by DNMRT

The ash content of tea leaves with hibiscus the addition of lime powder ranges between $7.56 \%$ up to $9.87 \%$. The highest value in the treatment of $\mathrm{A}$ (The addition of powdered lime 55\%), and the value the lowest in treatment $\mathrm{D}$ (addition of orange powder lime $85 \%$ ). These results comply with ISO standards Green tea dye mentioning 014324-1996 that the maximum ash content of 10\%. Ash content in tea decreased with increasing percentage powdered lime. Ash content in the raw material leaves hibiscus $9.97 \%$ while the ash content of the powder lime $1.41 \%$. So that ash content decreased by increasing the percentage of orange powder lime. According Sudarmadji [11], the ash is a substance an organic waste products of combustion of organic matter. The ash content and composition depending on the kinds of materials and combustion. Ash derived from mineral elements and chemical composition not evaporated during the incineration process.

3) Total Plate Count: The test results average total plate count the tea leaves of hibiscus can be observed in Table 5 .

TABLE V

Number of Total Plate on TEa LeAF Flower SHOES WITH THE ADDITION OF ORANGE POWDER LIME

\begin{tabular}{|l|c|}
\hline \multicolumn{1}{|c|}{$\begin{array}{c}\text { Addition of Lime Powder } \\
(\boldsymbol{\%})\end{array}$} & $\begin{array}{c}\text { Total Plate Count } \\
(\text { CFU/ml) }\end{array}$ \\
\hline A $(55 \%)$ & $2,6 \times 10^{3}$ \\
\hline B $(65 \%)$ & $1,1 \times 10^{3}$ \\
\hline C $(75 \%)$ & $7,2 \times 10^{2}$ \\
\hline D $(85 \%)$ & $4,9 \times 10^{2}$ \\
\hline
\end{tabular}

Note: The numbers in the same column followed by small letters are not significantly different at the level of $5 \%$ by DNMRT 
Total plate count of the tea leaf flower shoes ranged between $4.9 \times 10^{2} \mathrm{CFU} / \mathrm{ml}$ to $2.6 \times 10^{3} \mathrm{CFU} / \mathrm{ml}$. The highest number of microbes contained in $\mathrm{A}$ treatment (addition of powdered lime $55 \%$ ) that is equal to $2.6 \times 10^{3}$ $\mathrm{CFU} / \mathrm{ml}$. The number of microbes lowest for the treatment $\mathrm{D}$ (additions powdered lime $85 \%$ ) is $4.9 \times 10^{2} \mathrm{CFU} / \mathrm{ml}$. Average total plate count the number of microbes contained the tea leaves of hibiscus tea accepted SNI Green 01-44531998 namely a maximum of $3 \times 10^{3} \mathrm{CFU} / \mathrm{ml}$. The addition of powdered lemon in tea leaves hibiscus affect microbial growth, the higher levels of powdered lime given the lower the growth of microbes. Powder lime are as antimicrobials. Increase lime powder that has a higher percent can inhibit the growth of microbes on tea hibiscus leaves. Plant genus Citrus is one of the essential oil producing plants which is a natural substance that has been is known to have an antibacterial effect. Oil Essential produced by plants from the Citrus genus contains mostly terpenes, siskuit terpenes aliphatic hydrocarbon derivative oxygenated, and aromatic hydrocarbons [6]. Hibiscus leaves useful for community, especially in the treatment of diseases caused by bacteria such as diarrhea, as contained antibacterial compounds are flavonoids, saponins, and polyphenols, these compounds can inhibit growth of bacteria in the body [17].

4) Total Polyphenols: Results of variance showed additions powdered lime no real effect on total leaf hibiscus tea polyphenols on the level real $\alpha 5 \%$. The average value of total polyphenols in tea leaves hibiscus can be seen in Table 6.

TABLE VI

Total Polyphenols of Tea Leaves Hibiscus with THE AdDition OF POWDERED LIME.

\begin{tabular}{|l|c|}
\hline \multicolumn{1}{|c|}{ Addition Powder Lime } & Total Polyphenols (\%) \\
\hline A $(55 \%)$ & 1,58 \\
\hline B $(65 \%)$ & 1,67 \\
\hline C $(75 \%)$ & 1,70 \\
\hline D $(85 \%)$ & 1,81 \\
\hline CC $=0,84 \%$ & \\
\hline
\end{tabular}

Note: The numbers in the same column followed by small letters are not significantly different at the level of $5 \%$ by DNMRT

Total polyphenols in tea leaves of hibiscus who added powdered lime powder produced ranged from $1.58 \%$ $1.81 \%$. value The highest are in treatment $\mathrm{D}$ (additions powdered lime $85 \%$ ) is $1.81 \%$. total polyphenol was lowest for the treatment of A (additions powdered lime 55\%) of $1.1 \%$. Total polyphenols of tea hibiscus leaves increased in number the addition of lime powder increased According Hariana [12], on flower leaves shoes chemical components that play a role increases total polyphenols is flavonoids that hibisetin contained in the leaves of hibiscus. Lemon also contains saponins and flavonoids acts as polyphenols that hesperidin (hesperetin7-rutinosida), tangeretin, naringin, eriocitrin, eriocitrocide.

5) Vitamin C: Results of analysis of variance of the vitamin $\mathrm{C}$ indrink tea with hibiscus leaves the addition of powdered lime produced showed that the addition of juice lime significant effect on vitamin $\mathrm{C}$ tea hibiscus leaves at $5 \%$ significance level. Average value vitamin $\mathrm{C}$ tea leaves with hibiscus the addition of powdered lime can be seen in Table 7.

TABLE VII

The Average Value of Vitamin C Tea Leaf Flower Shoes with THE ADDITION OF POWDERED LIME

\begin{tabular}{|l|c|}
\hline \multicolumn{1}{|c|}{ Addition Powder Lime } & Vitamin C (\%) \\
\hline A $(55 \%)$ & $0,15 \mathrm{a}$ \\
\hline B $(65 \%)$ & $0,16 \mathrm{a}$ \\
\hline C $(75 \%)$ & $0,21 \mathrm{~b}$ \\
\hline D $(85 \%)$ & $0,22 \mathrm{~b}$ \\
\hline CC $=0,03 \%$ & \\
\hline
\end{tabular}

Note: The numbers in the same column followed by small letters are not significantly different at the level of $5 \%$ by DNMRT

The average percentage of vitamin $\mathrm{C}$ in tea leaves hibiscus with the addition of orange powder lime ranged from $0.15 \%$ to $0.22 \%$. Level The highest vitamin C contained in the treatment $\mathrm{D}$ and contained the lowest levels of vitamin $\mathrm{C}$ in the treatment of $\mathrm{A}$. Vit $\mathrm{C}$ hibiscus tea leaf increased in number the addition of lime powder increased This because lemon juice contains vitamin $C$ ie $0.72 \mathrm{mg} / 100$ $\mathrm{g}$ and powdered leaves of hibiscus $0.26 \mathrm{mg} / 100 \mathrm{~g}$ so as to improve vitamin $\mathrm{C}$ content of hibiscus tea leaves.

6) Antioxidant Activity : Results of analysis of variance of the activity antioxidants in tea leaves with hibiscus the addition of powdered lime produced showed that the addition of juice lime significantly different at 5\% significance level to the antioxidant activity of tea leaf hibiscus with the addition of powdered lime produced. The average value of antioxidant activity of tea leaf flower shoes with the addition of powdered lime served in Table 8 .

TABLE VIII

The Average VAlue of ANTIOXIDANT ACTIVITy of Tea LEAVES Hibiscus WITH THE ADDITION OF POWDER LIME.

\begin{tabular}{|l|c|}
\hline \multicolumn{1}{|c|}{ Addition Powder Lime } & Antioxidant activity (\%) \\
\hline A $(55 \%)$ & $35,51 \mathrm{~d}$ \\
\hline B $(65 \%)$ & $31,99 \mathrm{c}$ \\
\hline C $(75 \%)$ & $24,22 \mathrm{~b}$ \\
\hline D $(85 \%)$ & $18,01 \mathrm{a}$ \\
\hline CC $=1,63 \%$ & \\
\hline
\end{tabular}

Note: The numbers in the same column followed by small letters are not significantly different at the level of 5\% by DNMRT

In Table 8 . It can be seen that the activity antioxidant tea leaves with hibiscus the addition of lime powder ranges between $18.01 \%$ - $35.51 \%$ at a concentration of $2500 \mathrm{ppm}$. value activity The highest antioxidant contained in the treatment of A 6 (The addition of powdered lime 55\%), ie $35.51 \%$ and the value of the lowest antioxidant activity contained in D treatment (addition of powdered lime 85\%) ie $18.01 \%$. When compared with the raw material antioxidant activity of all treatment products lower compared with the antioxidant activity the raw material powder hibiscus leaves. that matter because there is no addition of powdered lime, because the acid from the lime can bind antioxidants in the products so the content antioxidants by adding powdered lime increasing reduce the content antioxidants on each product. 
The content of antioxidants found in the leaves hibiscus comes from flavonoids, saponins and polyphenols. Flavonoids are compounds potential phenolic antioxidant and has bioactivity as usual medications found in green plants, except algae [18]. Orange juice contains vitamin $\mathrm{C}$ which is acid thus able to reduce the content antioxidants from the tea leaves of hibiscus Based Lagho research results [19], stating compound phenol classified into tannins, coumarins, quinones, flavonoid, anthocyanin, floroglusinol, and lignans. Phenol compounds tend to be alkaline, soluble in water, and will be broken on the addition of acid, because bond $\mathrm{H}+$ in the acid would cut hydroxyl group the bond phenol. In addition to the heating process High temperatures can damage the antioxidant content because in the process of making flower leaf powder shoes using the oven at $70^{\circ} \mathrm{C}$ and manufacture of lime powder using a spray dryer with inlet temperature of $160^{\circ} \mathrm{C}$ and outlet temperature of $80^{\circ} \mathrm{C}$.

7) Sensory Analysis : Sensory analysis is a process identification, measurement, scientific analysis and interpretation of product attributes through the five senses human senses: the sense of sight, smell, tasting, touch and hearing. Election the use of trained panelists whether or not trained is an important factor in planning sensory analysis [20]. Sensory Analysis were performed using hedonic test by hedonic scale of 1 to 5: $1=$ Highly Dislike, $2=$ Dislike, $3=$ Fair, 4 = Like, 5 = Very Like. Results of the assessment panel. The next tabulated based distribution panelists assessment. The figures in the table are the percentage of panelists for each parameter selection test. In determining the most preferred products done by adding up the value of the percentage of panelists who expressed love to really like and the amount of the highest value is declared as the best product test results. Acceptance panelists who expressed love and really like that obtained through Sensory Analysis to color, taste and flavor of tea leaves flower shoes with the addition of powdered lime can seen in the following discussion.

8) Taste : From the results of sensory analysis conducted against the four tea products to the level of preference in terms of taste, the results obtained percentage shown in Table 9 below.

TABLE IX

The Results of The TAste Test of The TeA LeAves Hibiscus WITH THE ADDITION OF LIME POWDER

\begin{tabular}{|c|c|c|c|c|c|c|}
\hline \multirow{2}{*}{$\begin{array}{c}\text { Addition } \\
\text { Powder } \\
\text { Lime }\end{array}$} & \multicolumn{6}{|c|}{ Panelists Passions Levels } \\
\cline { 2 - 7 } & ED & DL & F & L & VL & VL and L \\
\hline A (55\%) & 0 & 20 & 35 & 40 & 5 & 45 \\
\hline B (65\%) & 5 & 15 & 40 & 30 & 10 & 40 \\
\hline C (75\%) & 0 & 25 & 35 & 25 & 10 & 35 \\
\hline D (85\%) & 5 & 30 & 35 & 30 & 0 & 30 \\
\hline
\end{tabular}

Information $\mathrm{ED}=$ Extremely Dislike; L=Like; F=Fair; L= Like; VL= Very Like;

In Table 9 it can be seen that the percentage A level panellists to taste of the tea ranges between $30 \%$ to $45 \%$. Taste of most products A much preferred is a product (powder Additions lime 55\%) with the percentage of A panellist $45 \%$ and flavor products are less preferred by the panellists Product is D (addition of powdered lime 85\%) with a percentage of $30 \%$ A panellist.

The addition of lime powder to tea hibiscus leaves affect the taste produced. The more the addition of orange powder lime, then the preference level panellists to taste product decreases, because the level of acidity product stronger and cause a bitter taste. Sourness in lime fruit caused by high citric acid content as much citric acid 7 to $7.6 \%$ [5]. Bitter taste found in lime caused by limonene [19]. The compound economically important as the basis of natural fragrances and also for spices as well as flavor compounds in the industry food [21].

According Setyaningsih [20], sensitivity to taste varies depending on the substance tested. The sensation generated by the trigeminal nerve located at the mouth and nose. Several factors which affect the ability of the panelists in Tasting include: fatigue adaptation panelists, genetic disorders, smoking habits.

9) Flavor : From the results of sensory analysis conducted against the four tea products to the level of preference in terms of flavor, the results obtained percentage listed in Table 10 below.

TABLE X

Results of Testing The Flavor of The Tea Leaves Hibiscus WITH THE ADDITION OF POWDER LIME

\begin{tabular}{|c|c|c|c|c|c|c|}
\hline \multirow{2}{*}{$\begin{array}{c}\text { Addition } \\
\text { Powder } \\
\text { Lime }\end{array}$} & \multicolumn{6}{|c|}{ Panelists Passions Levels } \\
\cline { 2 - 7 } & ED & DL & F & L & VL & VL and L \\
\hline A (55\%) & 0 & 0 & 25 & 65 & 10 & 75 \\
\hline B (65\%) & 0 & 0 & 25 & 65 & 10 & 75 \\
\hline C (75\%) & 0 & 0 & 35 & 55 & 10 & 65 \\
\hline D (85\%) & 0 & 0 & 35 & 55 & 5 & 60 \\
\hline
\end{tabular}

Information ED= Extremely Dislike; L=Like; F=Fair; L= Like; VL= Very Like;

Based on Table 10. Flavor in tea leaves hibiscus with the addition of powdered lime of four treatment preferred by the panelists are A treatment (addition of powdered lime 55\%) and treatment B (addition of powdered lime 65\%) the percentage rate that is like and very like $75 \%$. For the lowest acceptance rate panelists there are in treatment $\mathrm{D}$ (orange powder Additions lime $85 \%$ ) of $60 \%$. The resulting aroma in tea hibiscus leaves with the addition of orange powder namely the distinctive flavor of lemon acid and fresh because the orange powder. On the orange juice contains compounds that can produce a scent that is oil Essential as limonene and linalool [23].

The addition of lime can also cover the distinctive aroma of the leaves of the hibiscus leaves so distinctive aroma produced acid. Case such as, the content of flavonoids contained in the leaves of hibiscus affect flavor, because it contains flavonoids aromatic system conjugated. The role of the scent of a product is very important because it will determine consumer acceptance to the product. Flavor also determines the delicacy of a food product, as well as taste consists of three components, namely smell, taste and oral stimulation [10].

10) Color : From the results of sensory analysis conducted against the four tea products to the level of 
preference in terms of color, then the results obtained percentage listed in Table 11 below.

TABLE XI

Results of Testing The Color of THE TeA LeAves Hibiscus WITH THE ADDITION OF POWDER LIME.

\begin{tabular}{|c|c|c|c|c|c|c|}
\hline $\begin{array}{c}\text { Addition } \\
\text { Powder } \\
\text { Lime }\end{array}$ & \multicolumn{6}{|c|}{ Panelists Passions Levels } \\
\cline { 2 - 7 } & ED & DL & F & L & VL & VL and L \\
\hline A (55\%) & 0 & 10 & 35 & 45 & 10 & 55 \\
\hline B (65\%) & 0 & 10 & 40 & 45 & 5 & 50 \\
\hline C (75\%) & 0 & 10 & 25 & 50 & 15 & 65 \\
\hline D (85\%) & 0 & 10 & 20 & 60 & 15 & 70 \\
\hline
\end{tabular}

Information $\mathrm{ED}=$ Extremely Dislike; L=Like; F=Fair; L= Like; VL= Very Like;

Based on Table 11, the color of the tea leaves hibiscus with the addition of orange powder lime of four treatment preferred by the panelists is the treatment D (addition of powdered lime $85 \%$ ) with the highest percentage of love and love ie $70 \%$. For the lowest acceptance rate panelists there are in treatment B (Addition orange powder lime 65\%) is $50 \%$. Hibiscus tea leaf color with the addition of lemon is yellow powder little green. Color giver component in tea leaves fireworks with the addition of powdered lime allegedly flavonoid (hibisetin) whose role in the formation of greenish yellow color on hibiscus leaves [13]. the higher it is the level of addition of lemon juice then color steeping the tea becomes murky yellow. This is because chlorophyll is broken because coupled with lemon so the color is fading.

Color is crucial in the reception the impression of a person in a food tasting. Acceptance of a color different materials depends on natural factors, geographical, and social aspects receiving communities. Color used as quality parameters of materials. In addition, color can also be used as an indicator of freshness or maturity. Whether or how the mixing or way processing can be characterized by their color uniformly and evenly [10].

Based on the results of organoleptic test by five valuation parameters used are $1=$ Extremely Dislike (ED), 2 = Do not Like (DL), 3 = Fair (F), $4=$ Like (L), and $5=$ Very Likes (VL) to color, flavor, and taste produced can taken one of the most favored treatment by panelists. Where in determining a treatment The most preferred panelists can be seen in Table 12.

TABLE XII

RESUME SENSORy ANALysis RESUlts OF LEAVES TEA HiBisCUS FlOWER WITH THE ADDITION OF POWDER LIME.

\begin{tabular}{|c|c|c|c|}
\hline \multirow{2}{*}{$\begin{array}{c}\text { Addition } \\
\text { Powder } \\
\text { Lime }\end{array}$} & \multicolumn{3}{|c|}{$\begin{array}{c}\text { Panelists Passions Levels Like } \\
\text { and Very Likes }\end{array}$} \\
\cline { 2 - 4 } & Taste & Flavor & Color \\
\hline A (55\%) & 45 & 75 & 55 \\
\hline B (65\%) & 40 & 75 & 50 \\
\hline C (75\%) & 35 & 65 & 65 \\
\hline D (85\%) & 30 & 60 & 70 \\
\hline
\end{tabular}

Table 12. Based concluded that treatment preferred by the panelists as a whole which include color, flavor, and taste of tea leaves hibiscus with the addition of powdered lime namely the treatment of A (Addition of powdered lime 55\%) to the total percentage of the overall value of $175 \%$. Overall sensory analysis results can illustrated on the graph sensory analysis of tea leaves hibiscus with the addition of powdered extract lime. Here is a chart of test radar sensory analysis which can be seen in Figure 1.

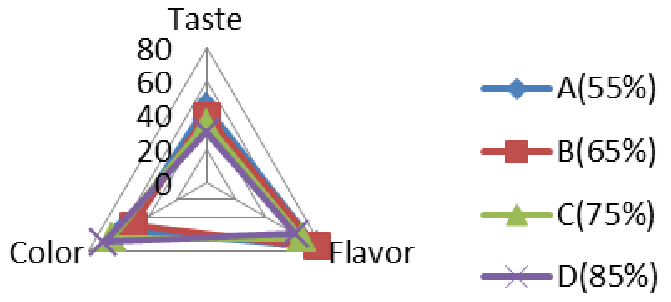

Fig. 1. Sensory Analysis of Leaves Tea Hibiscus Flower

From this graph it can be seen that the tea leaves hibiscus with the addition of powdered lime preferred by the panelists is the product in the treatment of $\mathrm{A}$ (The addition of powdered lime 55\%), which more either of the parameters of taste and aroma. While The best color parameters indicated by $\mathrm{D}$ treatment (addition of powdered lime $85 \%$ ).

\section{CONCLUSIONS}

The addition of powdered lime in manufacture of leaf tea hibiscus significant effect on water content, content ash, vitamin $\mathrm{C}$ and antioxidant activity. Based on the sensory analysis, then elected The best products tea leaf hibiscus with the addition of powdered lime is in the treatment of $\mathrm{A}$ (Addition of orange powder lime 55\%) with a $45 \%$ level of taste preferences, $75 \%$ aroma and color of $55 \%$. Results of the analysis chemistry performed on products A treatment (addition of powdered lime 55\%) obtained the value of vitamin $\mathrm{C} 0.15 \%$, total $1.58 \%$ polyphenols, antioxidant activity of $35.51 \%$, total plate count was 2.83 x $103 \mathrm{cfu} / \mathrm{ml}$, concentration water $7,76 \%$ and ash content of 9.87 .

Based on the research that has performed, the authors suggest further research in order to observe the shelf life of tea leaves hibiscus and the addition of other materials to improve the taste of acid in tea because the addition of powdered lime higher causing the tea is very acidic so it does not panellists preferred.

\section{REFERENCES}

[1] Hartoyo, A. 2009. Tea and usefulness for Health. Kanisius. Yogyakarta.

[2] Departemen of Health Republic Indonesia, 1985. Indonesian Medicinal Plants. Book I. Jakarta

[3] Anonymous. 2009. Test Principle, Leaflet Blood Glucose Test Strips Gluco Dr.

[4] Widjayakusuma, H., Wirian, U.S., Yaputra, T., Daimartha, S., and Wibowo, B., 1994, Plant Efficacious Drug. Volume Secondly, Moulds Second. Library Kartini. Jakarta.

[5] Hariana, A. 2006. Plant Medicine and Usefulness Series 1. Penebar Swadya. Jakarta

[6] Astarini dan Putu. N.F. 2010. Essential Oil of Citrus grandis and Citrus aurantifolia as Antibacterial Compound and Insecticides. . Technology Newletter and Journals Food Industry Vol.16. No.2

[7] Ahza, B, A dan Slamef, H, A 1997.Microencapsulation Mixture Peel and Lemon as well as Its Application in Tea Bags. Technology Newletter and Journals Food Industry Vol.3 No.2

[8] Arinfin.1994. Tea Processing Technical Instructions. Tea Research Center and Kina Gambung. Bandung.

[9] National Standardization Agency Indonesia.1995. Black Tea Dye. (SNI 01-3753-1995) BSN. Jakarta 
[10] Winarno, F.G. 2004. Food Chemistry and Nutrition. PT Gramedia Pustaka Utama. Jakarta.

[11] Sudarmadji, S. Haryono, B and Suharmi. 1997. Procedure for The analysis of Foodstuffs and Agricultural $4^{\text {th }}$ edition. Liberty Yogyakarta.

[12] Almatsier, S. 2004. Basic Principles of Nutrition. Gramedia. Jakarta.

[13] Hariana, A. 2008. Medicinal Plants and Usefulness Series 2. Matter to 6. Penebar Organization. Jakarta.

[14] Estiasih, T., and Sovia, E. 2009. Stability Antioxidants Keluwak powder (Pangium edule, Reinw.) During Drying and ripening. Faculty Agricultural Technology. Brawijaya University. Malang.

[15] National Standardization Agency of Indonesia. 1996. Green Tea Dye. (SNI 01-4324- 1996). BSN. Jakarta

[16] Buckle, KA, Edwards, RA, Fleet, GH, and Wootton, M. 2009. Food Science. translated by Adiono, H.P. University Of Indonesia Press. Jakarta.
[17] Suriana N and Sobarani I. 2011. Encyclopedia of Medicinal Plants Malang East Jawa

[18] Markham, K.R. 1988. Techniques of Flavonoids Identification translated by Kosasih Padmawinata ITB.Bandung.

[19] Lagho ABA 2010. Creation of Database Structure Three Dimensional Chemical Compounds From Plants Drugs in Indonesia. Faculty of Mathematics and Natural Sciences. University of Indonesia. Jakarta.

[20] Setyaningsih, D. Apriyantono, A. and Puspitasari, S,M. 2010 Sensory Analysis for Food and Agro Industries. IPB Press. Bogor

[21] Arintawati, M. (1992). Changes Studying Physics Chemical and Siam Citrus Fruit (Citrus nobilis var microcarpa) and Reduction Process Taste in Making Concentrate Bitter. Thesis. TPG, FATETAIPB. Bogor.

[22] Harborne, J.B., 1987. Methods Phytochemicals, ITB, Bandung

[23] Dalimartha, S. 2000. Atlas of Medicinal Plants Indonesia Volume I. Poster Agriwidya: Jakarta. 